\title{
Using social and behavioural science to support COVID-19 pandemic response
}

\author{
Jay J. Van Bavel ${ }^{1 凶}$, Katherine Baicker ${ }^{(1)}{ }^{2}$, Paulo S. Boggio $\mathbb{1}^{3}$, Valerio Capraro4, \\ Aleksandra Cichocka ${ }^{5,6}$, Mina Cikara ${ }^{17}{ }^{7}$, Molly J. Crockett $\mathbb{D}^{8}$, Alia J. Crum ${ }^{9}$, Karen M. Douglas $\mathbb{D}^{5}$, \\ James N. Druckman ${ }^{10}$, John Drury ${ }^{11}{ }^{11}$, Oeindrila Dube ${ }^{2}$, Naomi Ellemers ${ }^{12}$, Eli J. Finkel ${ }^{13}$, \\ James H. Fowler ${ }^{14}{ }^{14}$, Michele Gelfand ${ }^{15}{ }^{15}$, Shihui Han ${ }^{10}{ }^{16}$, S. Alexander Haslam (1) 17, Jolanda Jetten $\left(1{ }^{18}\right.$, \\ Shinobu Kitayama ${ }^{19}$, Dean Mobbs $\mathbb{D}^{20}$, Lucy E. Napper ${ }^{21}$, Dominic J. Packer ${ }^{22}$, Gordon Pennycook ${ }^{23}$, \\ Ellen Peters $\mathbb{D}^{24}$, Richard E. Petty ${ }^{25}{ }^{25}$, David G. Rand ${ }^{26}$, Stephen D. Reicher ${ }^{27}$, Simone Schnall ${ }^{28,29}$, \\ Azim Shariff ${ }^{30}$, Linda J. Skitka ${ }^{31}$, Sandra Susan Smith ${ }^{32}$, Cass R. Sunstein ${ }^{33}{ }^{33}$, Nassim Tabri ${ }^{34}$, \\ Joshua A. Tucker ${ }^{35}$, Sander van der Linden ${ }^{28}{ }^{28}$, Paul van Lange ${ }^{36}$, Kim A. Weeden ${ }^{37}$, \\ Michael J. A. Wohl (1) ${ }^{34}$, Jamil Zaki ${ }^{9}$, Sean R. Zion ${ }^{9}{ }^{9}$ and Robb Willer ${ }^{38} \bowtie$
}

The COVID-19 pandemic represents a massive global health crisis. Because the crisis requires large-scale behaviour change and places significant psychological burdens on individuals, insights from the social and behavioural sciences can be used to help align human behaviour with the recommendations of epidemiologists and public health experts. Here we discuss evidence from a selection of research topics relevant to pandemics, including work on navigating threats, social and cultural influences on behaviour, science communication, moral decision-making, leadership, and stress and coping. In each section, we note the nature and quality of prior research, including uncertainty and unsettled issues. We identify several insights for effective response to the COVID-19 pandemic and highlight important gaps researchers should move quickly to fill in the coming weeks and months.

\begin{abstract}
n December 2019, a new coronavirus (SARS-CoV-2) emerged, sparking an epidemic of acute respiratory syndrome (COVID19) in humans, centred in Wuhan, China ${ }^{1}$. Within three months, the virus had spread to more than 118,000 cases and caused 4,291 deaths in 114 countries, leading the World Health Organization to declare a global pandemic. The pandemic has led to a massive
\end{abstract}

global public health campaign to slow the spread of the virus by increasing hand washing, reducing face touching, wearing masks in public and physical distancing.

While efforts to develop pharmaceutical interventions for COVID-19 are under way, the social and behavioural sciences can provide valuable insights for managing the pandemic and its

'Department of Psychology \& Neural Science, New York University, New York, NY, USA. ${ }^{2}$ University of Chicago Harris School of Public Policy, Chicago, IL, USA. ' ${ }^{3}$ Social and Cognitive Neuroscience Laboratory, Center for Health and Biological Sciences, Mackenzie Presbyterian University, São Paulo, Brazil. ${ }^{4}$ Department of Economics, Middlesex University London, London, UK. ${ }^{5}$ School of Psychology, University of Kent, Kent, UK. ${ }^{6}$ Department of Psychology, Nicolaus Copernicus University, Toruń, Poland. ${ }^{7}$ Department of Psychology, Harvard University, Cambridge, MA, USA. ${ }^{8}$ Department of Psychology, Yale University, New Haven, CT, USA. ' Department of Psychology, Stanford University, Stanford, CA, USA. ${ }^{10}$ Department of Political Science, Northwestern University, Chicago, IL, USA. "'Department of Social Psychology, University of Sussex, Sussex, UK. ${ }^{12}$ Faculty of Social Sciences, Utrecht University, Utrecht, The Netherlands. ${ }^{13}$ Department of Psychology and the Kellogg School of Management, Northwestern University, Chicago, IL, USA. ${ }^{14}$ Division of Infectious Diseases and Global Public Health and Department of Political Science, University of California, San Diego, San Diego, CA, USA. ${ }^{15}$ Department of Psychology, University of Maryland, College Park, MD, USA. ${ }^{16}$ School of Psychological and Cognitive Sciences, PKU-IDG/McGovern Institute for Brain Research, Peking University, Beijing, China. ${ }^{17}$ University of Queensland, Brisbane, Australia. ${ }^{18}$ School of Psychology, University of Queensland, Brisbane, Australia. ${ }^{19}$ Department of Psychology, University of Michigan, Ann Arbor, MI, USA. ${ }^{20}$ Department of Humanities and Social Sciences and Computation and Neural Systems Program, California Institute of Technology, Pasadena, CA, USA. ${ }^{21}$ Department of Psychology and Health, Medicine \& Society Program, Lehigh University, Bethlehem, PA, USA. ${ }^{22}$ Department of Psychology, Lehigh University, Bethlehem, PA, USA. ${ }^{23} \mathrm{Hill} /$ Levene Schools of Business, University of Regina, Regina, Saskatchewan, Canada. ${ }^{24}$ School of Journalism and Communication, University of Oregon, Eugene, OR, USA. ${ }^{25}$ Department of Psychology, The Ohio State University, Columbus, OH, USA. ${ }^{26}$ Sloan School and Department of Brain and Cognitive Sciences, Massachusetts Institute of Technology, Boston, MA, USA. ${ }^{27}$ School of Psychology and Neuroscience, University of St. Andrews, St Andrews, UK. ${ }^{28}$ Department of Psychology University of Cambridge, Cambridge, UK. ${ }^{29}$ Bennett Institute for Public Policy, University of Cambridge, Cambridge, UK. ${ }^{30}$ Department of Psychology, University of British Columbia, Vancouver, British Columbia, Canada. ${ }^{31}$ Department of Psychology, University of Illinois at Chicago, Chicago, IL, USA. ${ }^{32}$ Department of Sociology, University of California, Berkeley, Berkeley, CA, USA. ${ }^{33}$ Harvard Law School, Harvard University, Cambridge, MA, United States. ${ }^{34}$ Department of Psychology, Carleton University, Ottawa, Ontario, Canada. ${ }^{35}$ Department of Politics, New York University, New York, NY, USA. ${ }^{36}$ Institute for Brain and Behavior Amsterdam, Department of Experimental and Applied Psychology, Vrije Universiteit Amsterdam, Amsterdam, The Netherlands. ${ }^{37}$ Department of Sociology, Cornell University, Ithaca, NY, USA. ${ }^{38}$ Department of Sociology, Stanford University, Stanford, CA, USA. $\bigotimes_{e}$-mail: jay.vanbavel@ nyu.edu; willer@stanford.edu 


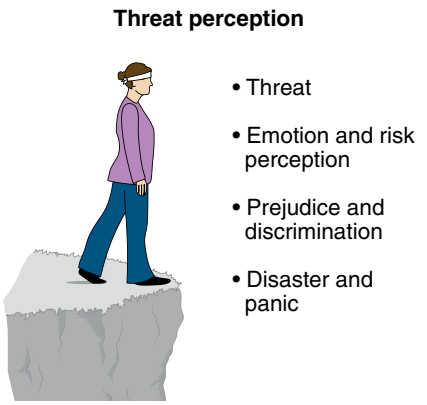

Science communication

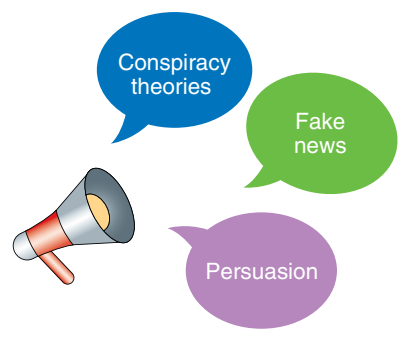

Leadership

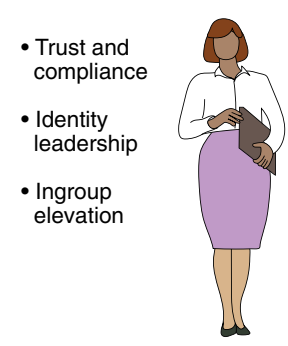

Social Context
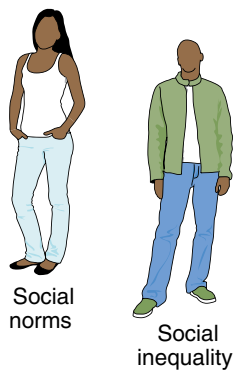

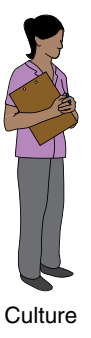

Individual and collective interests

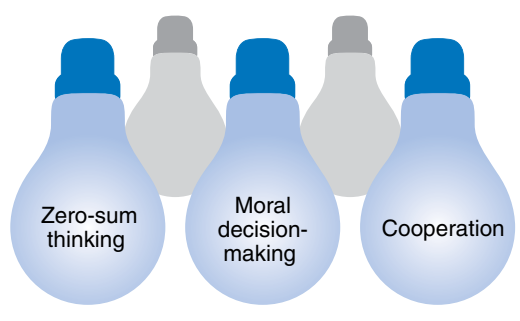

Stress and coping
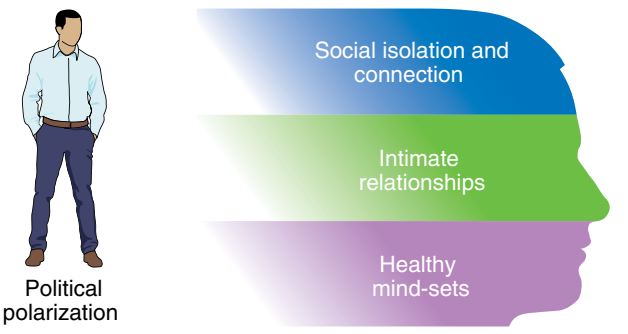

Fig. 1 | Infographic depicting a selection of topics from the social and behavioural sciences relevant during a pandemic. Topics covered here include threat perception, social context, science communication, individual and collective interests, leadership, and stress and coping.

impacts. We discuss topics that are broadly relevant to numerous stages of the current pandemic to help policy-makers, leaders and the public better understand how to manage threats, navigate different social and cultural contexts, improve science communication, align individual and collective interests, employ effective leadership and provide social and emotional support (see Fig. 1 for summary). For each area, we highlight relevant insights, discuss implications for policy makers, leaders and the public (Box 1) and note areas for future research.

Due to space constraints, this paper provides a brief summary of each topic. Research topics discussed here were identified by the corresponding authors as potentially relevant to pandemic response and thus are not exhaustive (for a review of research on specific actions, such as handwashing, face-touching and self-isolation, see ref. ${ }^{2}$ ). Furthermore, research on these topics is ongoing and, in many cases, far from settled. We have highlighted relevant findings in each area as well as critical gaps in the literature. Insights and implications for policy should be interpreted with caution because there is very little published social science research on the current pandemic. Thus, our discussion often draws from different circumstances than the current pandemic (for example, laboratory experiments examining hypothetical scenarios), and the quality of the evidence cited varies substantially (for example, correlational studies vs field experiments; single studies vs systematic reviews of substantial evidence). In the sections that follow, we try to describe the quality of evidence to facilitate careful, critical engagement by readers. We call for the scientific community to mobilize rapidly to produce research to directly inform policy and individual and collective behaviour in response to the pandemic.

Threat perception. Historically, infectious diseases have been responsible for the greatest human death tolls. For example, the bubonic plague killed approximately $25 \%$ of the European population $^{3}$. In this section, we discuss how people are likely to perceive and respond to threats and risk during a pandemic and downstream consequences for decision-making and intergroup relations.
Threat. One of the central emotional responses during a pandemic is fear. Humans, like other animals, possess a set of defensive systems for combating ecological threats ${ }^{4,5}$. Negative emotions resulting from threat can be contagious ${ }^{6}$, and fear can make threats appear more imminent ${ }^{7}$. A meta-analysis found that targeting fears can be useful in some situations, but not others: appealing to fear leads people to change their behaviour if they feel capable of dealing with the threat, but leads to defensive reactions when they feel helpless to act ${ }^{8}$. The results suggest that strong fear appeals produce the greatest behaviour change only when people feel a sense of efficacy, whereas strong fear appeals with low-efficacy messages produce the greatest levels of defensive responses.

Another challenge is that people often exhibit an 'optimism bias': the belief that bad things are less likely to befall oneself than others. While optimism bias may be useful for avoiding negative emotions ${ }^{9}$, it can lead people to underestimate their likelihood of contracting a disease $\mathrm{e}^{10}$ and to therefore ignore public health warnings ${ }^{11}$. Communication strategies must strike a balance between breaking through optimism bias without inducing excessive feelings of anxiety and dread.

Emotion and risk perception. Sound health decisions depend on accurate perceptions of the costs and benefits of certain choices for oneself and for society ${ }^{12,13}$. Emotions often drive risk perceptions, sometimes more so than factual information ${ }^{14,15}$. An emotional response to a risky situation can influence thinking in two stages ${ }^{16}$. First, the emotion's quality (for example, positive vs negative) focuses people on congruent information (for example, negative information when feeling negative). That information, rather than the feeling itself, is then used to guide judgment at the second stage. For example, smokers exposed to more negative emotional health warnings experienced more negative emotion toward warnings and smoking, spent more time examining warnings and recalled more risks, with subsequent effects on risk perception and quitting intentions ${ }^{17,18}$. As negative emotions increase, people may rely on negative information about COVID-19 more than other information to make decisions. 


\section{Box 1 | Social scientific insights for COVID-19 pandemic} response

We highlight some insights for public health experts, policy makers, and community leaders.

- A shared sense of identity or purpose can be encouraged by addressing the public in collective terms and by urging 'us' to act for the common good.

- Identifying sources (for example, religious or community leaders) that are credible to different audiences to share public health messages can be effective.

- Leaders and the media might try to promote cooperative behaviour by emphasizing that cooperating is the right thing to do and that other people are already cooperating.

- Norms of prosocial behaviour are more effective when coupled with the expectation of social approval and modelled by in-group members who are central in social networks.

- Leaders and members of the media should highlight bipartisan support for COVID-related measures, when they exist, as such endorsements in other contexts have reduced polarization and led to less-biased reasoning.

- There is a need for more targeted public health information within marginalized communities and for partnerships between public health authorities and trusted organizations that are internal to these communities.

- Messages that (i) emphasize benefits to the recipient, (ii) focus on protecting others, (iii) align with the recipient's moral values, (iv) appeal to social consensus or scientific norms and/ or (v) highlight the prospect of social group approval tend to be persuasive.

- Given the importance of slowing infections, it may be helpful to make people aware that they benefit from others' access to preventative measures.

- Preparing people for misinformation and ensuring they have accurate information and counterarguments against false information before they encounter conspiracy theories, fake news, or other forms of misinformation, can help inoculate them against false information.

- Use of the term 'social distancing' might imply that one needs to cut off meaningful interactions. A preferable term is 'physical distancing', because it allows for the fact that social connection is possible even when people are physically separated.

In the case of strong emotional reactions, people may also ignore important numeric information such as probabilities ${ }^{19}$ and a problem's scope ${ }^{20}$. Negative framing captures attention, especially for people who are less mathematically skilled ${ }^{21}$. The media usually report on COVID-19 negatively-for example, by reporting the number of people infected and those who die-as opposed to those who recover or experience only mild symptoms. This may increase negative emotion and sensitize people to otherwise neglected risks for themselves or others. Research is needed to determine whether a more positive frame could educate the public and relieve negative emotions while increasing public health behaviours.

Prejudice and discrimination. The experience of fear and threat has ramifications not only for how people think about themselves, but also how they feel about and react to others-in particular, out-groups. For instance, being threatened with disease is often associated with higher levels of ethnocentrism ${ }^{22}$; greater fear and perceived threat are associated with greater intolerance and punitive attitudes toward out-groups ${ }^{23-25}$. Highlighting group boundaries can undermine empathy with those who are socially distant $^{26,27}$ and increase dehumanization ${ }^{28}$ or punishment ${ }^{29}$.

The bubonic plague, for example, unleashed massive violence in Europe, including the murder of Catalans in Sicily, clerics and beggars in some locations, and pogroms against Jews, with over a thousand communities eradicated ${ }^{30}$. Although not every pandemic leads to violence, disease threat can nonetheless give rise to discrimination and violence against stigmatized or scapegoated groups. Already, there have been reports of physical attacks on ethnic Asian people in predominantly White countries, and some government officials mis-characterize SARS-CoV-2 as the 'Wuhan' or 'Chinese virus' ${ }^{31}$.

Conversely, a global pandemic may also create opportunities to reduce religious and ethnic prejudice. Coordinated efforts across individuals, communities and governments to fight the spread of disease can send strong signals of cooperation and shared values, which could facilitate reorganization of previously considered out-groups and in-groups into a single community with a common destiny. This 'superordinate categorization' is most effective when everyone is of equal status ${ }^{32}$. These cooperative acts are already unfolding in the current pandemic. For example, 21 countries donated medical supplies to China in February, and China has reciprocated widely. Highlighting events like these could improve out-group attitudes ${ }^{33}$ and foster further international cooperation.

Disaster and 'panic'. There is a common belief in popular culture that, when in peril, people panic, especially when in crowds. That is, they act blindly and excessively out of self-preservation, potentially endangering the survival of all ${ }^{34}$. This idea has been used to explain responses to the current COVID-19 outbreak, most commonly in relation to the notion of 'panic buying'. However, close inspection of what happens in disasters reveals a different picture. Certainly, some people do act selfishly and some, especially those who are particularly vulnerable, may experience more distress. But cooperation and orderly, norm-governed behaviour are common across a range of emergencies and disasters; and there are many instances when people display remarkable altruism ${ }^{35}$. There is already evidence that mutual aid groups among the public have become widespread in response to Covid- $19^{36}$. Indeed, in fires ${ }^{37}$ and other natural hazards ${ }^{38}$, people are less likely to die from over-reaction than from under-reaction, that is, not responding to signs of danger until it is too late.

In fact, the concept of 'panic' has largely been abandoned by researchers because it neither describes nor explains what people usually do in disaster ${ }^{39}$. Instead, the focus has shifted to the factors that explain why people cooperate rather than compete in response to crisis $^{35}$. One of these factors is an emerging sense of shared identity and concern for others, which arises from the shared experience of being in a disaster ${ }^{40}$. This feeling can be harnessed by addressing the public in collective terms and by urging 'us' to act for the common $\operatorname{good}^{41}$.

Conversely, the sense of shared identity can be undermined by representing others as competitors. This can happen with images of empty shelves and stories of panic buying, which suggest that others are only looking out for themselves, thus prompting a desire for doing the same. Stocking up on supplies is adaptive in preparation for potential self-isolation ${ }^{42}$. However, use of the notion of panic can be actively harmful. News stories that employ the language of panic often create the very phenomena that they purport to condemn. They can foster the very individualism and competitiveness that turns sensible preparations into dysfunctional stockpiling and undermine the sense of collective purpose which facilitates people supporting one another during an emergency.

\section{Social context}

Slowing viral transmission during pandemics requires significant shifts in behaviour. Various aspects of social and cultural contexts influence the extent and speed of behaviour change. In this 
section, we describe how aspects of the social context, such as social norms, social inequality, culture and polarization, may help decision-makers identify risk factors and effectively intervene.

Social norms. People's behaviour is influenced by social norms: what they perceive that others are doing or what they think that others approve or disapprove of ${ }^{43}$. A large literature has distinguished different motives for conformity to norms, including the desire to learn from other people and to gain affiliation or social approval $^{43,44}$. Although people are influenced by norms, their perceptions are often inaccurate ${ }^{45}$. For example, people can underestimate health-promoting behaviours (for example, hand washing ${ }^{46}$ ) and overestimate unhealthy behaviors ${ }^{47}$.

Changing behaviours by correcting such misperceptions can be achieved by public messages reinforcing positive (for example, health-promoting) norms. Providing accurate information about what most people are doing is likely to be helpful if what most people are doing is desirable (health-promoting). But if what most people are doing is not desirable, providing purely descriptive normative information can backfire by reducing positive behaviours among people who already engage in them, unless it is accompanied by information signalling that most people approve of these actions (prescriptive as opposed to descriptive norms) ${ }^{48,49}$. Perceived norms are also most influential when specific to others with whom common identities are shared ${ }^{50}$, including for the spread of health behaviors ${ }^{51}$. Therefore, messages that provide in-group models for norms (for example, members of your community) may therefore be most effective.

Social networks can amplify the spread of behaviours that are both harmful and beneficial during an epidemic, and these effects may spread through the network to friends, friends' friends and even friends' friends' friends ${ }^{52}$. The virus itself spreads from person to person, and since people centrally located in networks come into contact with more people, they are often among the first to be infected $^{53}$. But these very same central people may be instrumental in slowing the disease because they can spread positive interventions like hand washing and physical distancing by demonstrating them to a wide range of people ${ }^{54}$. Some research suggests that a larger proportion of interventions can come not from direct effects on people who receive the intervention, but from indirect effects on their social contacts who copied the behavior ${ }^{55}$. We may therefore leverage the impact of any behaviour change effort by targeting well-connected individuals and making their behaviour change visible and salient to others.

Another way to leverage the impact of norms falls under the general category of 'nudges ${ }^{56,57}$, which influence behaviour through modification of choice architecture (i.e., the contexts in which people make decisions). Because people are highly reactive to the choices made by others, especially trusted others, an understanding of social norms that are seen as new or emerging can have a positive impact on behavior ${ }^{58}$. For instance, a message with compelling social norms might say, 'the overwhelming majority of people in your community believe that everyone should stay home'. Nudges and normative information can be an alternative to more coercive means of behaviour change or used to complement regulatory, legal and other imposed policies when widespread changes must occur rapidly.

Social inequality. Inequalities in access to resources affect not only who is at greatest risk of infection, developing symptoms or succumbing to the disease, but also who is able to adopt recommendations to slow the spread of the disease. The homeless cannot shelter in place $^{59}$, families in housing without running water cannot wash their hands frequently ${ }^{60}$, people who are detained by a state (for example, in jails, prisons, immigrant detention centres or refugee camps) may lack space to implement physical distancing, people without health insurance may delay or avoid seeking testing or treatment, people who rely on public transportation cannot always avoid large crowds and low-wage workers are often in occupations (for example, service, retail, cleaning, agricultural labour) where remote work is impossible and employers do not offer paid sick leave ${ }^{61}$. Economic disadvantage is also associated with the pre-existing conditions associated with higher morbidity rates once infected, such as compromised immune systems, diabetes, heart disease and chronic lung diseases like asthma and chronic obstructive pulmonary disease ${ }^{62}$. We expect that, as in natural hazards, the economically disadvantaged will be most likely to be exposed to the hazard, most susceptible to harm from it and most likely to experience negative outcomes from it ${ }^{63,64}$.

Issues of economic disadvantage intersect with issues of race and ethnicity. Members of minority communities (such as blacks, Latinos and American Indians/Alaska Natives in the US) are disproportionately found among the homeless ${ }^{59}$, the detained, the workers in high public contact but low-benefit occupations ${ }^{65}$, and those with prior health conditions that make them more vulnerable ${ }^{66,67}$. Because social networks tend to be racially differentiated $^{68}$, members of minority communities who contract the disease may become vectors of transmission to others in their racial and ethnic communities ${ }^{69}$.

Economic position and racial inequality are also associated with levels of trust in social institutions, including the healthcare system. Racial and ethnic minority communities, in particular, have both historical and contemporary experiences of discrimination, leading to distrust ${ }^{70-74}$. Members of these communities may be more likely to be wary about the public health information they receive, less willing to adopt recommended safety measures and potentially more susceptible to 'fake news'. This suggests the need for more targeted public health information and for partnerships between public health authorities and trusted organizations that are internal to these communities.

Culture. A sense of the self as independent versus interdependent with others is a dimension of cultural variation ${ }^{75}$. Western European and North American cultures that endorse individualism ${ }^{76}$ are considered independent, whereas most other cultures share a stronger commitment to collectives such as country, tribe and family and are considered interdependent ${ }^{77,78}$. While medical policies are different across societies, some differences in the response to the pandemic may be better described as cultural, and many of those have a linkage to the dimension of independence vs interdependence. First, the priority given to obligations and duties in Asian societies may motivate individuals to remain committed to social norms while suppressing personal desires ${ }^{79}$. Second, Asians may more readily recognize unobservable situational influences on viral infection, like herd immunity ${ }^{80}$. Third, social norms and conventions in North America and much of Western Europe tend to positively value the expressivity of the self (for example, kissing, hugging, direct argumentation), relative to Asia ${ }^{81}$. This is another reason why interpersonal transmission of the virus could be more likely in independent cultures than in interdependent cultures.

Another, related, dimension of cultural variance is a society's 'tightness' vs 'looseness'. Research has found that tight cultures, such as those of Singapore, Japan and China, have strict social norms and punishments for deviance, while loose cultures, such as the US, Italy and Brazil, have weaker social norms and are more permissive ${ }^{82,83}$. Tight nations often have extensive historical and ecological threats, including greater historical prevalence of natural hazards, invasions, population density and pathogen outbreaks ${ }^{82,84}$. From an evolutionary perspective, when groups experience collective threats, strict rules may help them to coordinate to survive ${ }^{82,85}$. Therefore, the spread of COVID-19 infections may tighten communities. Cultures accustomed to prioritizing freedom over security may also have 
more difficulty coordinating in the face of a pandemic. It may also be relevant that communities negotiate social norms so that there is a balance between freedom and constraint, or 'tight-loose ambidexterity ${ }^{36}$. Tight rules regarding social distancing are critical, yet looseness within these constraints may also help to spawn the development of creative technical solutions that are needed to contain the pandemic, as well as creating novel tools to help people feel connected. The cumulative evidence here suggests that very different strategies might be called for in varying cultural contexts in the fight against COVID-19.

Political polarization. One cultural barrier for coordinated action within countries is political polarization. Polarization among citizens comes in two varieties. 'Attitudinal polarization' concerns partisans taking extreme opposing issue positions, whereas 'affective polarization' refers to partisans disliking and distrusting those from the opposing party(ies) ${ }^{87,88}$. Affective polarization has political consequences, such as decreasing trust ${ }^{89}$, privileging partisan labels over policy information ${ }^{90}$ and believing false information $^{91}$, that can undermine social and economic relationships ${ }^{88}$ and impair public health.

One issue with polarization during a pandemic is that it might lead different segments of the population to arrive at different conclusions about the threat in the situation and appropriate actions. Partisans may receive different news because individuals can self-select polarized news sources or partisan 'echo chambers' ${ }^{92,93}$ or can communicate in ways that are associated with less cross-partisan information sharing ${ }^{94}$. But in-person political interactions can provide more opportunity for cross-partisan communication ${ }^{95}$ (that produce a shared understanding). The decrease in in-person contact due to COVID-19 may reduce cross-partisan interactions and information sharing.

However, there are actionable steps that could reduce polarization. First, the pandemic not only highlights a common identity with individuals all facing the same risk, but could also foster a sense of shared fate. By highlighting an overarching identity, politicians, the media and opinion leaders could help reduce political division around the issue. Second, a growing body of work shows that misperceptions of the other side underlie polarization ${ }^{96,97}$. Therefore, it is likely important to combat misinformation that could generate partisan motivated reasoning and inaccurate beliefs (see "Fake news and misinformation" below). Finally, leaders can highlight bipartisan support for COVID-19-related measures, when they exist, as such endorsements in other contexts have reduced polarization and led to less biased reasoning ${ }^{98}$.

\section{Science communication}

The information environment around a pandemic underscores the importance of effective science communication. The COVID-19 pandemic has already seen a rise in conspiracy theories, fake news and misinformation ${ }^{99}$. In this context, it is hard for the public to distinguish scientific evidence and facts from less reliable sources of information. In this section, we discuss the challenges associated with different forms of misinformation during a pandemic, as well as strategies for engaging in effective science communication and persuasion around public health.

Conspiracy theories. Conspiracy theories emerged shortly after the first news of COVID-19 and have continued to persist ${ }^{99}$. Some concerned the origins of the SARS-CoV-2 virus, for example, that it was a bioweapon created by the Chinese to wage war on the US or vice versa ${ }^{100}$. Others focused on prevention and cure, for instance, that conventional medical treatment should not be trusted and that people should use alternative remedies to ward off the virus ${ }^{101}$. It is not surprising that conspiracy theories have flourished at this time. Research suggests that people feel the need to explain large events with proportionally large causes ${ }^{102}$ and are more likely to believe in conspiracy theories about events with serious consequences ${ }^{103}$ and in times of crisis ${ }^{104}$. This is likely because people are more drawn to conspiracy theories when important psychological needs are frustrated ${ }^{105}$. Thus, conspiracy theories may gain more traction as COVID-19 spreads and more people isolate themselves ${ }^{106}$.

These conspiracy theories can have harmful consequences. For example, belief in conspiracy theories has been linked to vaccine hesitancy ${ }^{107}$, climate denial ${ }^{108}$, extremist political views ${ }^{109}$ and prejudice $^{110,111}$. COVID-19 conspiracy theories may be similarly problematic. For instance, people who believe that alternative remedies can help them fight off the virus may be less likely to follow health officials' advice and instead opt for less effective (at best) or lethal (at worst) alternatives. Conspiracy beliefs may also fuel hostility toward groups seen as responsible for the virus ${ }^{112}$. Some evidence suggests that giving people factual information before exposure to conspiracy theories can reduce conspiracy theory beliefs ${ }^{113}$, and this strategy might work in efforts to combat conspiracy theories relevant to the current pandemic (see "Fake news and misinformation" below for similar findings). However, because some people tend to consume information within like-minded 'echo chambers', combating conspiracy theories remains a challenge ${ }^{114}$.

Fake news and misinformation. Fake news and misinformation about COVID-19 have proliferated widely on social media, with potentially dangerous consequences ${ }^{115}$. Emerging research is using social science to understand and counter the spread of fake news ${ }^{116-118}$. One approach is to debunk using fact-checking and correction $^{119-121}$. Source expertise, co-partisanship, exposing denial, and corrections that provide causal explanations all tend to increase the effectiveness of countering misinformation ${ }^{122-124}$. However, fact-checking may not keep up with the vast amount of false information produced in times of crisis like a pandemic. Moreover, there is mixed research regarding whether corrections may actually increase belief in the original misinformation ${ }^{121,124-126}$ or in other misleading claims that fail to get corrected ${ }^{127}$. Thus, other approaches beyond debunking are needed.

One 'prebunking' approach involves psychological inoculation ${ }^{128,129}$. Inoculation follows the biomedical analogy: people are exposed to a severely weakened dose of a persuasive argument, strong enough to trigger the immune system but not so strong as to overwhelm it. A meta-analysis has found inoculation effective in protecting attitudes from persuasion ${ }^{130}$. The fake news game Bad News is a real-world inoculation intervention (https://www. getbadnews.com) used by schools and governments that finds that pre-emptively exposing people to small doses of misinformation techniques (including scenarios about COVID-19) can reduce susceptibility to fake news ${ }^{131,132}$ and could be embedded directly on social media platforms ${ }^{133}$.

Another preventative approach involves subtle prompts that nudge people to consider accuracy. Evidence suggests that deliberation is associated with ${ }^{134-136}$ and causes ${ }^{137}$ reduced belief in false news headlines that circulated on social media. Platforms could nudge users to think about accuracy by, for example, periodically asking users to rate the accuracy of randomly selected posts. The crowdsourced accuracy ratings generated by this process may also be useful for identifying misinformation, as has been found for crowd ratings of source trustworthiness ${ }^{138,139}$.

To effectively counter fake news about COVID-19 around the world, governments and social media companies must rigorously develop and test interventions. This includes identifying treatments that effectively reduce belief in misinformation, while not undermining belief in accurate information ${ }^{140}$.

Persuasion. In the domain of science communication, scholars have explored a host of messaging approaches, including providing 
information in evidence-based ways that increase understanding and action ${ }^{141}$. Decades of research has found that, whether recipients are motivated to think carefully or not ${ }^{142}$, sources perceived as credible are more persuasive $e^{143}$. The credibility of sources stems from how trustworthy and expert they are perceived to be ${ }^{144}$. Enlisting trusted voices has been shown to make public health messages more effective in changing behaviour during epidemics. During the West African Ebola crisis, for example, religious leaders across faiths in Sierra Leone advocated for practices such as handwashing and safe burials. The engagement of the faith-based sector was considered a turning point in the epidemic response ${ }^{145}$. Therefore, finding credible sources for different audiences who are able to share public health messages might prove effective.

Once a credible source is identified, what message should be delivered? Several messaging approaches may be effective, including emphasizing the benefits to the recipient ${ }^{146}$, focusing on protecting others (for example, 'wash your hands to protect your parents and grandparents ${ }^{147}$ ), aligning with the recipient's moral values ${ }^{148}$, appealing to social consensus or scientific norms ${ }^{149-151}$ and/or highlighting social group approval ${ }^{152,153}$. Which of these messages work best depends on the audience's motivations ${ }^{154}$. Beyond finding effective messages for attitude change is the issue of inducing behavioural change. This occurs when people feel confident about their attitudes ${ }^{155}$. Methods to increase certainty include helping people feel knowledgeable about their new attitude ${ }^{156}$ and making them feel that their new attitude is the 'moral' one to have ${ }^{157}$. It may therefore be useful to identify which messages work best on which populations not only to generate policy support but also to ensure individuals' actions needed to combat the spread of the virus.

\section{Aligning individual and collective interests}

The behaviour of individuals living in communities is regulated by moral norms and values ${ }^{158-162}$. People who do what is 'right' are respected and publicly admired, while those who do what is 'wrong' are devalued and socially excluded ${ }^{163}$. These mechanisms of social enforcement encourage people to embrace and internalize shared guidelines, making them motivated to do what is considered right while avoiding behaviours that seem wrong ${ }^{164}$, and do not rely on legal agreements and formal sanctions ${ }^{165}$. In this section, we consider how research on morality and cooperation can encourage prosocial behaviours by individuals and groups.

Zero-sum thinking. People often default to thinking that someone else's gain-especially someone from a competing group-necessitates a loss to themselves, and vice versa ${ }^{166,167}$. Zero-sum thinking fits uneasily with the non-zero-sum nature of pandemic infection, where someone else's infection is a threat to oneself and everyone else ${ }^{168}$. Zero-sum thinking means that while it might be psychologically compelling to hoard protective materials (sanitizer, masks, even vaccines) beyond what is necessary, doing so could be self-defeating. Given the importance of slowing infections, it may be helpful to make people aware that others' access to preventative measures is a benefit to oneself.

Whereas reducing infections across the population is non-zero-sum, the provision of scarce health care resources to the infected does have zero-sum elements. For example, when the number of patients needing ventilators exceeds capacity, health care providers are often forced to make life-for-life trade-offs. How well the policies enacted match the local norms can help determine how much support they receive. While some people are willing to sacrifice the elderly to save the young ${ }^{169}$, there are cultural differences on this preference ${ }^{170}$. Who is perceived to be making those decisions may also impact the public's and patients' trust. In experiments, people who make utilitarian judgments about matters of life and death are less trusted ${ }^{171}$. American's trust in medical doctors remains high ${ }^{172}$, and compared to public health officials, doctors are less utilitarian in their ethical decision-making, opting instead for deontic 'do no harm' rules ${ }^{173}$. As such, it may be best to have decisions behind life-for-life trade-offs perceived as systematic and coming from governmental agencies rather than from physicians themselves.

Moral decision-making. Moral decision-making during a pandemic involves uncertainty. It's not certain whether social interactions will infect others. People may be less willing to make sacrifices for others when the benefits are uncertain ${ }^{174,175}$. For instance, in hypothetical scenarios about deciding whether to go to work while sick, American and British participants reported they would be less willing to stay home when it was uncertain they would infect a co-worker. However, when going to work risked infecting an elderly co-worker who would suffer a serious illness, participants reported they would be more willing to stay home ${ }^{176}$. Thus, focusing on worst-case scenarios, even if they are uncertain, may encourage people to make sacrifices for others.

When people make moral decisions, they often consider how others would judge them for behaving selfishly ${ }^{177,178}$. Harmful actions are judged more harshly than harmful inactions ${ }^{179,180}$, and causing harm by deviating from the status quo is blamed more than harming by default ${ }^{181,182}$. Therefore, reframing decisions to carry on with 'business as usual' during a pandemic as active decisions, rather than passive or default decisions, may make such behaviours less acceptable.

Cooperation within groups. Fighting a global pandemic requires large-scale cooperation. The problem is that, by definition, cooperation requires people to bear an individual cost to benefit other people $^{183}$. In particular, there is a conflict between short-term self-interest vs longer-term collective interest ${ }^{184}$. Moreover, in this pandemic, there are several collectives (for example, family, community, national and international) which can make decisions to cooperate challenging. From an evolutionary perspective, extending self-interest to protect and promote the welfare of family members should be a small step, as it increases genetic fitness. Indeed, laboratory research has found that people prioritize local over global (or international) interests ${ }^{185,186}$. One major question, then, is how to promote cooperation.

Several techniques, such as sanctioning defectors ${ }^{187}$ or rewarding cooperators $^{188}$, tend to increase cooperative behaviour in laboratory experiments using economic games. Providing cues that make the morality of an action salient (such as having people read the Golden Rule before making a decision or asking them to report what they think is the morally right thing to do) have also been shown to increase cooperation ${ }^{189,190}$. People are also more likely to cooperate when they believe that others are cooperating ${ }^{191}$. Accordingly, interventions based on observability and descriptive norms are highly effective at increasing cooperative behaviour in economic games as well as in the field ${ }^{192}$. This suggests that leaders and the media can promote cooperation by making these behaviours more observable.

Leadership. Crises like the COVID-19 pandemic create an opportunity for leadership across groups of varying levels: families, workplaces, local communities and nations. Leadership can coordinate individuals and help them avoid behaviours that are no longer considered socially responsible. In this section, we discuss the roles of trust and compliance with leaders, effective identity leadership and supporting group members.

Trust and compliance. During a pandemic, health officials often need to persuade the population to make a number of behaviour changes and follow health policies aimed at containment-e.g., honouring quarantine or reporting voluntarily for medical testing. By their nature and the scope of the population, such measures can 
be difficult to enforce. Research from the West Africa Ebola crisis of 2014-2015 suggests that enlisting local voices to help build engagement and trust in health officials can increase the success of such public health measures. For instance, specialized Ebola treatment facilities that employed community liaisons and social mobilizers to raise awareness and resolve misconceptions were associated with increases in reporting Ebola cases ${ }^{193}$. Correlational evidence from Liberia also suggests that explicit government efforts to reach out to the population, like door-to-door canvassing, are associated with compliance with crisis management policies like bans on gatherings ${ }^{194}$.

Trust in institutions and governments also may play an important role. For example, trust in the Liberian government was correlated with decisions to abide by mandated social distancing policies ${ }^{195}$ and using clinics for care during the Ebola outbreak ${ }^{196}$. Trust was also related to decisions to adopt preventive measures such as Ebola vaccinations in the Democratic Republic of Congo ${ }^{197}$. Conversely, a lack of trust in public health officials may lead to negative effects on utilization of health services ${ }^{198}$. Reliable information and public health messages are needed from national leaders and central health officials. But local voices can amplify these messages and help build the trust that is needed to spur behavioural change.

Identity leadership. Experimental studies clarify what leaders can do to promote trust leading to cooperation. A priority for leaders is to create a sense of shared social identity amongst their followers ${ }^{199}$. A large body of research suggests that people tend to prefer leaders who cultivate a sense that 'we are all in this together' ${ }^{200}$. In part, such leadership gives people a sense of collective self-efficacy and hope ${ }^{201}$. More importantly, though, it provides a psychological platform for group members to coordinate efforts to tackle stressors ${ }^{202}$. Without leadership, there is a risk that people will avoid acts of citizenship and instead embrace a philosophy of 'everyone for themselves'.

Leaders who are seen as prototypical of the group ('one of us') and as acting for the interest of the group as a whole ('working for us'), rather than for themselves or for another group, tend to gain greater influence ${ }^{203,204}$. Actions that divide the leader from followers or that suggest that the leader is not prepared to share the burdens of followers can be corrosive to their ability to shape followers' behaviour ${ }^{205}$. For instance, leaders who threaten people with sanctions as a way to deter undesired behaviour may make people feel distrusted and paradoxically reduce their willingness to do as they are told ${ }^{206}$. Leaders and authorities who treat people with respect, and who communicate that they trust people to do as they are told, tend to be more successful in eliciting cooperation ${ }^{207}$.

Elevating the in-group without demeaning others. Building a strong sense of shared social identity can help coordinate efforts to manage threats ${ }^{202}$ and foster in-group commitment and adherence to norms ${ }^{208}$. Leaders can do this, for instance, by being a source of 'moral elevation'. Visibly displaying prosocial and selfless acts can prompt observers to also act with kindness and generosity themselves ${ }^{209}$. In this way, leaders can function as role models and motivate people to put their own values into action ${ }^{210,211}$. Having respected politicians, celebrities and community leaders model exemplary behaviour and sacrifice could help promote prosocial behaviour and cooperation.

Excessive efforts to foster a sense of national unity by promoting the image of the nation as handling the situation exceptionally well can backfire, especially if there is no objective basis for this. An inflated belief in national greatness (i.e., 'collective narcissism' ${ }^{212}$ ) can be maladaptive in a number of ways. For instance, it is associated with a greater focus on defending the image of the country than on caring for its citizens ${ }^{213,214}$. It is also correlated with seeing out-groups as a threat and blaming them for in-group misfortunes ${ }^{215}$. To increase people's willingness to take a pandemic seriously and engage with other nations to defeat it, citizens and leaders may need to accept that their country is at risk, just like others, and find ways to share resources and expertise across national boundaries.

\section{Stress and coping}

Even for households free from the virus, the pandemic is likely to function as a major stressor, especially in terms of chronic anxiety and economic difficulties. Such effects may be exacerbated by self-isolation policies that can increase social isolation and relationship difficulties. In this section, we consider some strategies to mitigate the virus-linked threats to social connection, intimate relationships and stress.

Social isolation and connection. In the absence of a vaccine, one of the most vital strategies for slowing the pandemic is social distancing. However, distancing clashes with the deep-seated human instinct to connect with others ${ }^{216}$. Social connection helps people regulate emotions, cope with stress and remain resilient during difficult times ${ }^{217-220}$. By contrast, loneliness and social isolation worsen the burden of stress and often produce deleterious effects on mental, cardiovascular and immune health ${ }^{221,222}$. Older adults, who are at the greatest risk of severe symptoms from COVID-19, are also highly susceptible to isolation ${ }^{223}$. Distancing threatens to aggravate feelings of loneliness and could produce negative long-term health consequences.

Scholars have identified strategies that could mitigate these outcomes. First, in psychological terms, loneliness is construed as the subjective state that one is not experiencing enough social connection, whereas isolation is an objective lack of social interactions ${ }^{224}$. This means one can be isolated but not lonely, or lonely in a crowd. Thus, the term 'social distancing' might imply that one needs to cut off meaningful interactions. A useful alternative term might be 'physical distancing', to help highlight the fact that social connection is possible even when people are physically separated.

Online interactions can also foster a sense of connection. Both receiving and giving support online can bolster psychological well-being ${ }^{225}$. However, we caution against enhanced passive use of social media, as research suggests that it may not contribute to one's sense of social connection ${ }^{226,227}$. Instead, technologies that are informationally rich, dyadic and temporally synchronous appear better suited to generating empathy and connection ${ }^{228,229}$. Special attention should be placed on helping people who are less familiar with these technologies to learn how to take advantage of digital connections.

Intimate relatinships. The social effects of the pandemic also extend to the inside of our homes, where many people find themselves in sudden forced proximity with their immediate family. People subject to quarantine or self-isolation are at risk for confusion and anger ${ }^{230}$, emotional tendencies that can be explosive when multiple household members simultaneously endure them for weeks or months on end. Indeed, some studies suggest that forced proximity is a risk factor for aggression ${ }^{231,232}$ and domestic violence ${ }^{233}$.

Even without forced proximity, stress, including economic stress $^{234}$, is linked to relationship difficulties. It often changes the content of social interactions (for example, more focus on unpleasant logistics, less focus on emotional connection) and undermines the psychological resources, like empathy and patience, that make challenging interactions go smoothly ${ }^{235}$. A study of the effects of Hurricane Hugo in 1989, for example, revealed that harder-hit areas experienced a spike in the divorce rate ${ }^{236}$. The news is not all bad, however: the hurricane study also documented surging marriage and birth rates ${ }^{236}$.

Major stressors, it seems, alter the trajectories of our intimate relationships, but researchers are still unpacking when, why and for whom these effects are harmful vs beneficial. But one factor underlying success is for individuals to calibrate their expectations to the 
circumstances, a process that will vary from couple to couple and from partner to partner ${ }^{237}$. The recalibration process involves both (i) lowering broad expectations that the course of true love in the time of COVID-19 will run smoothly while also (ii) sustaining high expectations in those domains where the relationship can deliver in these conditions.

Healthy mind-sets. In the face of a global pandemic, avoiding stress altogether is simply not an option. Fortuitously, the past twenty years of research on coping and stress suggest that it's not the type or amount of stress that determines its impact. Rather, mind-sets and situation appraisals about stress can alter its impact ${ }^{238,239}$. For instance, some research finds these mind-sets can increase the possibility of 'stress-related growth', a phenomenon in which stressful experiences serve to increase physiological toughening ${ }^{240-242}$, help reorganize our priorities and can help lead to deeper relationships and a greater appreciation for life $\mathrm{e}^{243}$.

Preliminary research suggests that mind-sets about stress can be changed with short and targeted interventions. These interventions do not focus on viewing the stressor (such as the virus) as less of a threat ${ }^{244}$. Instead, they invite people to recognize that we tend to stress about things we care deeply about and that we can harness the stress response for positive gain. A number of studies found that inducing more adaptive mind-sets about stress could increase positive emotion, reduce negative health symptoms and boost physiological functioning under acute stress ${ }^{244,245}$. Research is needed to see if adopting these mind-sets can help some people harness the stress during a pandemic for positive growth.

\section{Conclusion}

Over 100 years ago, Science magazine published a paper on lessons from the Spanish Flu pandemic ${ }^{246}$. The paper argued that three main factors stand in the way of prevention: (i) people do not appreciate the risks they run, (ii) it goes against human nature for people to shut themselves up in rigid isolation as a means of protecting others, and (iii) people often unconsciously act as a continuing danger to themselves and others. Our paper provides some insights from the past century of work on related issues in the social and behavioural sciences that may help public health officials mitigate the impact of the current pandemic. Specifically, we discussed research on threat perception, social context, science communication, aligning individual and collective interests, leadership, and stress and coping. These are a selection of relevant topics, but readers may also be interested in other relevant work, including on psychological reactance ${ }^{247,248}$, collective emotions and social media ${ }^{249,250}$, and the impact of economic deprivation and unemployment ${ }^{251,252}$.

Urgent action is needed to mitigate the potentially devastating effects of COVID-19, action that can be supported by the behavioural and social sciences. However, many of the implications outlined here may also be relevant to future pandemics and public health crises. A recent report ${ }^{253}$ from the World Health Organization declared that "health communication is seen to have relevance for virtually every aspect of health and well-being, including disease prevention, health promotion and quality of life."

Received: 24 March 2020; Accepted: 9 April 2020;

Published online: 30 April 2020

\section{References}

1. Zhou, F. et al. Clinical course and risk factors for mortality of adult inpatients with COVID-19 in Wuhan, China: a retrospective cohort study. Lancet 395, 1054-1062 (2020).

2. Lunn, P. et al. Using behavioural science to help fight the coronavirus. ESRI Working Paper No. 656 March 2020. http://aei.pitt.edu/102644/ (2020).

3. Scott, S. \& Duncan, C.J. Biology of Plagues: Evidence from Historical Populations. (Cambridge University Press, 2001).

4. LeDoux, J. Rethinking the emotional brain. Neuron 73, 653-676 (2012).
5. Mobbs, D., Hagan, C. C., Dalgleish, T., Silston, B. \& Prévost, C. The ecology of human fear: survival optimization and the nervous system. Front. Neurosci. 9, 55 (2015).

6. Kramer, A. D. I., Guillory, J. E. \& Hancock, J. T. Experimental evidence of massive-scale emotional contagion through social networks. Proc. Natl Acad. Sci. USA 111, 8878-8790 (2014).

7. Cole, S., Balcetis, E. \& Dunning, D. Affective signals of threat increase perceived proximity. Psychol. Sci. 24, 34-40 (2013).

8. Witte, K. \& Allen, M. A meta-analysis of fear appeals: implications for effective public health campaigns. Health Educ. Behav. 27, 591-615 (2000).

9. Strunk, D. R., Lopez, H. \& DeRubeis, R. J. Depressive symptoms are associated with unrealistic negative predictions of future life events. Behav. Res. Ther. 44, 861-882 (2006).

10. Sharot, T. The optimism bias. Curr. Biol. 21, R941-R945 (2011).

11. Wise, T., Zbozinek, T. D., Michelini, G., Hagan, C. C. \& Mobbs, D. Changes in risk perception and protective behavior during the first week of the COVID-19 pandemic in the United States. Preprint at PsyArXiv https://osf. io/dz428 (2020).

12. Fischhoff, B. The sciences of science communication. Proc. Natl Acad. Sci. USA 110(Suppl 3), 14033-14039 (2013).

13. Slovic, P. Perception of risk. Science 236, 280-285 (1987).

14. Slovic, P., Finucane, M. L., Peters, E. \& MacGregor, D. G. Risk as analysis and risk as feelings: some thoughts about affect, reason, risk, and rationality. Risk Anal. 24, 311-322 (2004).

15. Loewenstein, G. F., Weber, E. U., Hsee, C. K. \& Welch, N. Risk as feelings. Psychol. Bull. 127, 267-286 (2001).

16. Peters, E., Lipkus, I. \& Diefenbach, M. A. The functions of affect in health communications and in the construction of health preferences. J. Commun. 56, S140-S162 (2006).

17. Evans, A. T. et al. Graphic warning labels elicit affective and thoughtful responses from smokers: results of a randomized clinical trial. PLoS One 10, e0142879 (2015).

18. Noar, S. M. et al. Pictorial cigarette pack warnings: a meta-analysis of experimental studies. Tob. Control 25, 341-354 (2016).

19. Rottenstreich, Y. \& Hsee, C. K. Money, kisses, and electric shocks: on the affective psychology of risk. Psychol. Sci. 12, 185-190 (2001).

20. Hsee, C. K. \& Rottenstreich, Y. Music, pandas, and muggers: on the affective psychology of value. J. Exp. Psychol. Gen. 133, 23-30 (2004).

21. Peters, E. et al. Numeracy and decision making. Psychol. Sci. 17, 407-413 (2006).

22. Schaller, M. \& Neuberg, S. L. Danger, disease, and the nature of prejudice(s). Advances in Experimental Social Psychology 46, 1-54 (2012).

23. Feldman, S. \& Stenner, K. Perceived threat and authoritarianism. Polit. Psychol. 18, 741-770 (1997).

24. Jackson, J. C. et al. Ecological and cultural factors underlying the global distribution of prejudice. PLoS One 14, e0221953 (2019).

25. Marcus, G. E., Sullivan, J. L., Theiss-Morse, E. \& Wood, S. L. With Malice Toward Some: How People Make Civil Liberties Judgments. (Cambridge Univ. Press, 1995).

26. Cikara, M., Bruneau, E. G. \& Saxe, R. R. Us and them: intergroup failures of empathy. Curr. Dir. Psychol. Sci. 20, 149-153 (2011).

27. Han, S. Neurocognitive basis of racial ingroup bias in empathy. Trends Cogn. Sci. 22, 400-421 (2018).

28. Kteily, N., Hodson, G. \& Bruneau, E. They see us as less than human: metadehumanization predicts intergroup conflict via reciprocal dehumanization. J. Pers. Soc. Psychol. 110, 343-370 (2016).

29. Han, X. et al. A neurobiological association of revenge propensity during intergroup conflict. eLife 9, e52014 (2020).

30. Cohn, S. K. Pandemics: waves of disease, waves of hate from the Plague of Athens to A.I.D.S. Hist. J. 85, 535-555 (2012).

31. Russell, A. The rise of coronavirus hate crimes. The New Yorker https://www.newyorker.com/news/letter-from-the-uk/ the-rise-of-coronavirus-hate-crimes (2020).

32. Dovidio, J. F., Gaertner, S. L. \& Saguy, T. Another view of "we": majority and minority group perspectives on a common ingroup identity. Eur. Rev. Soc. Psychol. 18, 296-330 (2007).

33. Wright, S. C., Aron, A., McLaughlin-Volpe, T. \& Ropp, S. A. The extended contact effect: knowledge of cross-group friendships and prejudice. J. Pers. Soc. Psychol. 73, 73-90 (1997).

34. Clarke, L. Panic: myth or reality? Contexts 1, 21-26 (2002).

35. Drury, J. The role of social identity processes in mass emergency behaviour: an integrative review. Eur. Rev. Soc. Psychol. 29, 38-81 (2018).

36. Booth, R. Community aid groups set up across UK amid coronavirus crisis. The Guardian https://www.theguardian.com/society/2020/mar/16/ community-aid-groups-set-up-across-uk-amid-coronavirus-crisis (16 March 2020).

37. Canter, D. Fires and Human Behaviour. (David Fulton, 1990).

38. Tierney, K.J., Lindell, M.K. \& Perry, R.W. Facing the Unexpected: Disaster Preparedness and Response in the United States. (Joseph Henry Press, 2001). 
39. Quarantelli, E.L. Sociology of panic. in International Encyclopedia of the Social and Behavioural Sciences (eds. Smelser, N. J. \& Baltes, P. B.) 11020-11023 (Pergamon Press, 2001).

40. Drury, J., Cocking, C. \& Reicher, S. The nature of collective resilience: survivor reactions to the 2005 London bombings. Int. J. Mass Emerg. Disasters 27, 66-95 (2009).

41. Carter, H., Drury, J., Rubin, G. J., Williams, R. \& Amlôt, R. Applying crowd psychology to develop recommendations for the management of mass decontamination. Health Secur. 13, 45-53 (2015).

42. Stiff, C. The game theory of panic-buying - and how to reduce it The Conversation http://theconversation.com/ the-game-theory-of-panic-buying-and-how-to-reduce-it-134107 (2020).

43. Cialdini, R. B. \& Goldstein, N. J. Social influence: compliance and conformity. Annu. Rev. Psychol. 55, 591-621 (2004).

44. Wood, W. Attitude change: persuasion and social influence. Annu. Rev. Psychol. 51, 539-570 (2000).

45. Miller, D.T. \& Prentice, D.A. The construction of social norms and standards. in Social Psychology: Handbook of Basic Principles 799-829 (Guilford Press, 1996).

46. Dickie, R., Rasmussen, S., Cain, R., Williams, L. \& MacKay, W. The effects of perceived social norms on handwashing behaviour in students. Psychol. Health Med. 23, 154-159 (2018).

47. Berkowitz, A.D. An overview of the social norms approach. in Changing the Culture of College Drinking: A Socially Situated Health Communication Campaign (eds. Stewart, L. \& Lederman, L. C.) 193-214 (Hampton Press, 2005).

48. Cialdini, R.B., Kallgren, C.A. \& Reno, R.R. A focus theory of normative conduct: a theoretical refinement and reevaluation of the role of norms in human behavior. in Advances in Experimental Social Psychology 24, 201-234 (1991).

49. Schultz, P. W., Nolan, J. M., Cialdini, R. B., Goldstein, N. J. \& Griskevicius, $\mathrm{V}$. The constructive, destructive, and reconstructive power of social norms. Psychol. Sci. 18, 429-434 (2007).

50. Abrams, D., Wetherell, M., Cochrane, S., Hogg, M. A. \& Turner, J. C. Knowing what to think by knowing who you are: self-categorization and the nature of norm formation, conformity and group polarization. Br. J. Soc. Psychol. 29, 97-119 (1990)

51. Centola, D. An experimental study of homophily in the adoption of health behavior. Science 334, 1269-1272 (2011).

52. Christakis, N. A. \& Fowler, J. H. Social contagion theory: examining dynamic social networks and human behavior. Stat. Med. 32, 556-577 (2013).

53. Christakis, N. A. \& Fowler, J. H. Social network sensors for early detection of contagious outbreaks. PLoS One 5, e12948 (2010).

54. Kim, D. A. et al. Social network targeting to maximise population behaviour change: a cluster randomised controlled trial. Lancet $\mathbf{3 8 6}$ 145-153 (2015).

55. Bond, R. M. et al. A 61-million-person experiment in social influence and political mobilization. Nature 489, 295-298 (2012).

56. Halpern, D. Inside the Nudge Unit: How Small Changes Can Make a Big Difference (Random House, 2015).

57. Thaler, R.H. \& Sunstein, C.R. Nudge: Improving Decisions About Health, Wealth, and Happiness. (Yale University Press, 2008).

58. Sparkman, G. \& Walton, G. M. Dynamic norms promote sustainable behavior, even if it is counternormative. Psychol. Sci. 28, 1663-1674 (2017).

59. HUD Continuum of Care Homeless Assistance Programs Homeless Populations and Subpopulations. https://files.hudexchange.info/reports/ published/CoC_PopSub_NatlTerrDC_2019.pdf (US Department of Housing \& Urban Development, 2019).

60. Deitz, S. \& Meehan, K. Plumbing poverty: mapping hot spots of racial and geographic inequality in U.S. household water insecurity. Ann. Am. Assoc. Geogr. 109, 1092-1109 (2019).

61. Bureau of Labor Statistics, U.S. Department of Labor. Higher wage workers more likely than lower wage workers to have paid leave benefits in 2018 The Economics Daily https://www.bls.gov/opub/ted/2018/higher-wageworkers-more-likely-than-lower-wage-workers-to-have-paid-leave-benefitsin-2018.htm (2018)

62. Cockerham, W. C., Hamby, B. W. \& Oates, G. R. The social determinants of chronic disease. Am. J. Prev. Med. 52(1S1), S5-S12 (2017).

63. Fothergill, A. \& Peek, L. A. Poverty and disasters in the United States: review of recent sociological findings. Nat. Hazards 32, 89-110 (2004).

64. Bolin, B. \& Kurtz, L.C. Race, class, ethnicity, and disaster vulnerability. in Handbook of Disaster Research (eds. Rodríguez, H., Donner, W. \& Trainor, J. E.) 181-203 (Springer International Publishing, 2018)

65. Kristal, T., Cohen, Y. \& Navot, E. Benefit inequality among American workers by gender, race, and ethnicity, 1982-2015. Sociol. Sci. 5 , 461-488 (2018).

66. National Academies of Sciences, Engineering, and Medicine. Communities in Action: Pathways to Health Equity. (National Academies Press, 2017).
67. Quiñones, A. R. et al. Racial/ethnic differences in multimorbidity development and chronic disease accumulation for middle-aged adults. PLoS One 14, e0218462 (2019).

68. Marsden, P. V. Core discussion networks of Americans. Am. Sociol. Rev. 52, 122-131 (1987).

69. Granovetter, M. S. The strength of weak ties. Am. J. Sociol. 78, 1360-1380 (1973)

70. Demaris, A. \& Yang, R. Race, alienation, and interpersonal mistrust. Sociol. Spectr. 14, 327-349 (1994).

71. Brehm, J. \& Rahn, W. Individual-level evidence for the causes and consequences of social capital. Am. J. Pol. Sci. 41, 999-1023 (1997).

72. Smith, T. W. Factors relating to misanthropy in contemporary American society. Soc. Sci. Res. 26, 170-196 (1997).

73. Claibourn, M. P. \& Martin, P. S. Trusting and Joining? An empirical test of the reciprocal nature of social capital. Polit. Behav. 22, 267-291 (2000).

74. Alesina, A. \& La Ferrara, E. Who trusts others? J. Public Econ. 85 207-234 (2002).

75. Markus, H. R. \& Kitayama, S. Culture and the self: Implications for cognition, emotion, and motivation. Psychol. Rev. 98, 224-253 (1991).

76. Triandis, H.C. Individualism And Collectivism. (Westview Press, 1995).

77. Kitayama, S., Park, H., Sevincer, A. T., Karasawa, M. \& Uskul, A. K. A cultural task analysis of implicit independence: comparing North America, Western Europe, and East Asia. J. Pers. Soc. Psychol. 97, 236-255 (2009).

78. San Martin, A. et al. Self-assertive interdependence in Arab culture. Nat. Hum. Behav. 2, 830-837 (2018).

79. Kitayama, S. et al. Behavioral adjustment moderates the link between neuroticism and biological health risk: a U.S.-Japan comparison study. Pers. Soc. Psychol. Bull. 44, 809-822 (2018).

80. Betsch, C., Böhm, R., Korn, L. \& Holtmann, C. On the benefits of explaining herd immunity in vaccine advocacy. Nat. Hum. Behav. 1, 56 (2017).

81. Kraus, B. \& Kitayama, S. Interdependent self-construal predicts emotion suppression in Asian Americans: an electro-cortical investigation. Biol. Psychol. 146, 107733 (2019).

82. Gelfand, M. J. et al. Differences between tight and loose cultures: a 33-nation study. Science 332, 1100-1104 (2011).

83. Gelfand, M. J., Harrington, J. R. \& Jackson, J. C. Perspect. Psychol. Sci. 12 800-809 (2017). The strength of social norms across human groups.

84. Harrington, J. R. \& Gelfand, M. J. Tightness-looseness across the 50 United States. Proc. Natl Acad. Sci. USA 111, 7990-7995 (2014).

85. Roos, P., Gelfand, M., Nau, D. \& Lun, J. Societal threat and cultural variation in the strength of social norms: an evolutionary basis. Organ. Behav. Hum. Decis. Process. 129, 14-23 (2015).

86. Gelfand, M. Rule Makers, Rule Breakers: How Tight and Loose Cultures Wire Our World. (Scribner, 2018).

87. Westwood, S. J. et al. The tie that divides: cross-national evidence of the primacy of partyism. Eur. J. Polit. Res. 57, 333-354 (2018).

88. Iyengar, S., Lelkes, Y., Levendusky, M., Malhotra, N. \& Westwood, S. J. The origins and consequences of affective polarization in the United States. Annu. Rev. Polit. Sci. 22, 129-146 (2019).

89. Hetherington, M.J. \& Weiler, J.D. Authoritarianism and polarization in American politics, still? in American Gridlock: The Sources, Character, and Impact of Polarization (eds. Thurber, J. A. \& Yoshinaka, A.) 86-112 (Cambridge Univ. Press, 2015).

90. Abramowitz, A. I. \& Webster, S. The rise of negative partisanship and the nationalization of U.S. elections in the 21st century. Elect. Stud. 41, 12-22 (2016).

91. Van Bavel, J. J. \& Pereira, A. The partisan brain: an identity-based model of political belief. Trends Cogn. Sci. 22, 213-224 (2018).

92. Bakshy, E., Messing, S. \& Adamic, L. A. Political science. Exposure to ideologically diverse news and opinion on Facebook. Science 348, 1130-1132 (2015).

93. Lelkes, Y., Sood, G. \& Iyengar, S. The hostile audience: the effect of access to broadband internet on partisan affect. Am. J. Pol. Sci. 61, 5-20 (2017).

94. Brady, W. J., Wills, J. A., Jost, J. T., Tucker, J. A. \& Van Bavel, J. J. Emotion shapes the diffusion of moralized content in social networks. Proc. Natl Acad. Sci. USA 114, 7313-7318 (2017).

95. Minozzi, W., Song, H., Lazer, D. M. J., Neblo, M. A. \& Ognyanova, K. The incidental pundit: who talks politics with whom, and why? Am. J. Pol. Sci. 64, 135-151 (2020).

96. Ahler, D. J. \& Sood, G. The parties in our heads: misperceptions about party composition and their consequences. J. Polit. 80, 964-981 (2018).

97. Lees, J. \& Cikara, M. Inaccurate group meta-perceptions drive negative out-group attributions in competitive contexts. Nat. Hum. Behav. 4, 279-286 (2020).

98. Bolsen, T., Druckman, J. N. \& Cook, F. L. The influence of partisan motivated reasoning on public opinion. Polit. Behav. 36, 235-262 (2014).

99. Ellis, E.G. The coronavirus outbreak is a petri dish for conspiracy theories. Wired https://www.wired.com/story/coronavirus-conspiracy-theories/ (2020) 
100. Gertz, B. Coronavirus may have originated in lab linked to China's biowarfare program. The Washington Times https://www.washingtontimes. com/news/2020/jan/26/coronavirus-link-to-china-biowarfare-programpossi/ (2020).

101. Sommer, W. QAnon-ers' magic cure for coronavirus: just drink bleach! The Daily Beast https://www.thedailybeast.com/qanon-conspiracy-theoristsmagic-cure-for-coronavirus-is-drinking-lethal-bleach (2020).

102. Leman, P. \& Cinnirella, M. A major event has a major cause: evidence for the role of heuristics in reasoning about conspiracy theories. Soc. Psychol. Rev. 9, 18-28 (2007).

103. McCauley, C. \& Jacques, S. The popularity of conspiracy theories of presidential assassination: a Bayesian analysis. J. Pers. Soc. Psychol. 37, 637-644 (1979).

104. van Prooijen, J.-W. \& Douglas, K. M. Conspiracy theories as part of history: the role of societal crisis situations. Mem. Stud. 10, 323-333 (2017).

105. Douglas, K. M., Sutton, R. M. \& Cichocka, A. The psychology of conspiracy theories. Curr. Dir. Psychol. Sci. 26, 538-542 (2017).

106. Graeupner, D. \& Coman, A. The dark side of meaning-making: how social exclusion leads to superstitious thinking. J. Exp. Soc. Psychol. 69, 218-222 (2017).

107. Jolley, D. \& Douglas, K. M. The effects of anti-vaccine conspiracy theories on vaccination intentions. PLoS One 9, e89177 (2014).

108. Lewandowsky, S., Gignac, G. E. \& Oberauer, K. The robust relationship between conspiracism and denial of (climate) science. Psychol. Sci. 26, 667-670 (2015).

109. van Prooijen, J.-W., Krouwel, A. P. M. \& Pollet, T. V. Political extremism predicts belief in conspiracy theories. Soc. Psychol. Personal. Sci. 6, 570-578 (2015).

110. Jolley, D., Meleady, R. \& Douglas, K. M. Exposure to intergroup conspiracy theories promotes prejudice which spreads across groups. Br. J. Psychol. 111, 17-35 (2020).

111. Kofta, M., Soral, W. \& Bilewicz, M. What breeds conspiracy antisemitism? The role of political uncontrollability and uncertainty in the belief in Jewish conspiracy. J. Pers. Soc. Psychol. https://doi.org/10.1037/pspa0000183 (2020).

112. Marchlewska, M., Cichocka, A., Łozowski, F., Górska, P. \& Winiewski, M. In search of an imaginary enemy: Catholic collective narcissism and the endorsement of gender conspiracy beliefs. J. Soc. Psychol. 159, 766-779 (2019).

113. Jolley, D. \& Douglas, K. M. Prevention is better than cure: addressing anti-vaccine conspiracy theories. J. Appl. Soc. Psychol. 47, 459-469 (2017).

114. Zollo, F. et al. Debunking in a world of tribes. PLoS One 12, e0181821 (2017).

115. Frenkel, S., Alba, D. \& Zhong, R. Surge of virus misinformation stumps Facebook and Twitter. The New York Times https://www.nytimes.com/ 2020/03/08/technology/coronavirus-misinformation-social-media.html (2020).

116. Allen, J., Howland, B., Mobius, M., Rothschild, D. \& Watts, D. J. Evaluating the fake news problem at the scale of the information ecosystem. Sci. Adv. 1, eaay3539 (2020).

117. Allcott, H. \& Gentzkow, M. Social media and fake news in the 2016 election. J. Econ. Perspect. 31, 211-236 (2017).

118. Guess, A., Nagler, J. \& Tucker, J. Less than you think: prevalence and predictors of fake news dissemination on Facebook. Sci. Adv. 5, u4586 (2019).

119. Berinsky, A. J. Rumors and health care reform: experiments in political misinformation. Br. J. Polit. Sci. 47, 241-262 (2017).

120. Lewandowsky, S., Ecker, U. K. H., Seifert, C. M., Schwarz, N. \& Cook, J. Misinformation and its correction: continued influence and successful debiasing. Psychol. Sci. Public Interest 13, 106-131 (2012).

121. Guess, A. \& Coppock, A. Does counter-attitudinal information cause backlash? Results from three large survey experiments. Br. J. Polit. Sci. https://doi.org/10.1017/S0007123418000327 (2018).

122. Schmid, P. \& Betsch, C. Effective strategies for rebutting science denialism in public discussions. Nat. Hum. Behav. 3, 931-939 (2019).

123. Nyhan, B. \& Reifler, J. Displacing misinformation about events: an experimental test of causal corrections. J. Exp. Political Sci. 2, 81-93 (2015).

124. Wittenberg, C. \& Berinsky, A.J. Misinformation and its correction. in Social Media and Democracy: The State of the Field (eds Persily, N. \& Tucker, J. A.) (Cambridge University Press, forthcoming).

125. Swire, B. \& Ecker, U.K.H. Misinformation and its correction: Cognitive mechanisms and recommendations for mass communication. in Misinformation and Mass Audiences (eds. Southwell, B. G., Thorson, E. A. \& Sheble, L.) 195-2011 (University of Texas Press, 2018).

126. Wood, T. \& Porter, E. The elusive backfire effect: mass attitudes' steadfast factual adherence. Polit. Behav. 41, 135-163 (2018).

127. Pennycook, G., McPhetres, J., Zhang, Y. \& Rand, D. Fighting COVID-19 misinformation on social media: Experimental evidence for a scalable accuracy nudge intervention. Preprint at PsyArXiv https://doi.org/10.31234/ osf.io/uhbk9 (2020).

128. McGuire, W. J. Some contemporary approaches. Advances in Experimental Social Psychology 1, 191-229 (1964).
129. van der Linden, S., Leiserowitz, A., Rosenthal, S. \& Maibach, E. Inoculating the public against misinformation about climate change. Glob. Chall. 1, 1600008 (2017).

130. Banas, J. A. \& Rains, S. A. A meta-analysis of research on inoculation theory. Commun. Monogr. 77, 281-311 (2010).

131. Basol, M., Roozenbeek, J. \& van der Linden, S. Good news about bad news: gamified inoculation boosts confidence and cognitive immunity against fake news. J. Cogn. 3, 2 (2020).

132. Roozenbeek, J. \& van der Linden, S. Fake news game confers psychological resistance against online misinformation. Palgrave Commun. 5, 65 (2019).

133. Roozenbeek, J., van der Linden, S. \& Nygren, T. Prebunking interventions based on "inoculation" theory can reduce susceptibility to misinformation across cultures. Harv. Kennedy Sch. Misinformation Rev. https://doi. org/10.37016//mr-2020-008 (2020).

134. Pennycook, G. \& Rand, D. G. Lazy, not biased: susceptibility to partisan fake news is better explained by lack of reasoning than by motivated reasoning. Cognition 188, 39-50 (2019).

135. Pennycook, G. \& Rand, D. G. Who falls for fake news? The roles of bullshit receptivity, overclaiming, familiarity, and analytic thinking. J. Pers. $\mathbf{8 8}$, 185-200 (2020).

136. Bronstein, M. V., Pennycook, G., Bear, A., Rand, D. G. \& Cannon, T. D. Belief in fake news is associated with delusionality, dogmatism, religious fundamentalism, and reduced analytic thinking. J. Appl. Res. Mem. Cogn. 8, 108-117 (2019).

137. Bago, B., Rand, D. G. \& Pennycook, G. Fake news, fast and slow: deliberation reduces belief in false (but not true) news headlines. J. Exp. Psychol. Gen. https://psycnet.apa.org/doi/10.1037/xge0000729 (2020).

138. Dias, N., Pennycook, G. \& Rand, D. G. Emphasizing publishers does not effectively reduce susceptibility to misinformation on social media. Harv. Kennedy Sch. Misinformation Rev. https://doi.org/10.37016/mr-2020-001 (2020).

139. Pennycook, G. \& Rand, D. G. Fighting misinformation on social media using crowdsourced judgments of news source quality. Proc. Natl Acad. Sci. USA 116, 2521-2526 (2019).

140. Clayton, K. et al. Real solutions for fake news? Measuring the effectiveness of general warnings and fact-check tags in reducing belief in false stories on social media. Polit. Behav. https://doi.org/10.1007/s11109-019-09533-0 (2019).

141. Trevena, L.J. et al. Presenting quantitative information about decision outcomes: a risk communication primer for patient decision aid developers. BMC Med. Inform. Decis. Mak. 13 Suppl 2, S7 (2013).

142. Petty, R. E. \& Cacioppo, J. T. The elaboration likelihood model of persuasion. Advances in Experimental Social Psychology 19, 123-205 (1986).

143. Briñol, P. \& Petty, R. E. Source factors in persuasion: a self-validation approach. Eur. Rev. Soc. Psychol. 20, 49-96 (2009).

144. O'Keefe, D.J. Persuasion: Theory and Research. (SAGE, 2016).

145. Greyling, C. et al. Lessons from the faith-driven response to the West Africa Ebola epidemic. Rev. Faith Int. Aff. 14, 118-123 (2016).

146. Teeny, J., Siev, J., Briñol, P. \& Petty, R.E. A review and conceptual framework for understanding personalized matching effects in persuasion. J. Consum. Psychol. (in the press).

147. Grant, A. M. \& Hofmann, D. A. It's not all about me: motivating hand hygiene among health care professionals by focusing on patients. Psychol. Sci. 22, 1494-1499 (2011).

148. Feinberg, M. \& Willer, R. Moral reframing: a technique for effective and persuasive communication across political divides. Soc. Personal. Psychol. Compass 13, e12501 (2019).

149. Lewandowsky, S., Gignac, G. E. \& Vaughan, S. The pivotal role of perceived scientific consensus in acceptance of science. Nat. Clim. Chang. 3, 399-404 (2013).

150. Linden, S. V., Leiserowitz, A. \& Maibach, E. Scientific agreement can neutralize politicization of facts. Nat. Hum. Behav. 2, 2-3 (2018).

151. van der Linden, S., Leiserowitz, A. \& Maibach, E. The gateway belief model: a large-scale replication. J. Environ. Psychol. 62, 49-58 (2019).

152. Drummond, C. \& Fischhoff, B. Individuals with greater science literacy and education have more polarized beliefs on controversial science topics. Proc. Natl Acad. Sci. USA 114, 9587-9592 (2017).

153. Kahan, D. M. et al. The polarizing impact of science literacy and numeracy on perceived climate change risks. Nat. Clim. Chang. 2, $732-735$ (2012).

154. Druckman, J. N. \& McGrath, M. C. The evidence for motivated reasoning in climate change preference formation. Nat. Clim. Chang. 9, 111-119 (2019).

155. Rucker, D., Tormala, Z. L., Petty, R. E. \& Briñol, P. Consumer conviction and commitment: an appraisal-based framework for attitude certainty. J. Consum. Psychol. 24, 119-136 (2014).

156. Barden, J. \& Petty, R. E. The mere perception of elaboration creates attitude certainty: exploring the thoughtfulness heuristic. J. Pers. Soc. Psychol. 95, 489-509 (2008).

157. Luttrell, A., Petty, R. E., Briñol, P. \& Wagner, B. C. Making it moral: merely labeling an attitude as moral increases its strength. J. Exp. Soc. Psychol. 65, 82-93 (2016). 
158. Greene, J. Moral Tribes: Emotion, Reason, and the Gap between Us and Them (Penguin Press, 2013).

159. Haidt, J. The emotional dog and its rational tail: a social intuitionist approach to moral judgment. Psychol. Rev. 108, 814-834 (2001).

160. Haidt, J. The Righteous Mind: Why Good People Are Divided by Politics and Religion. (Vintage, 2012).

161. Tomasello, M. Why We Cooperate. (MIT Press, 2009).

162. Tooby, J. \& Cosmides, L. Groups in mind: the coalitional roots of war and morality. in Human Morality and Sociality (ed. Høgh-Olesen, H.) 191-234 (2010).

163. Leach, C.W., Bilali, R. \& Pagliaro, S. Groups and morality. in APA handbook of Personality and Social Psychology, Volume 2: Group Processes 123-149 (American Psychological Association, 2015).

164. Ellemers, N. Morality and the Regulation of Social Behavior. (Routledge, 2017).

165. Ellemers, N. \& van den Bos, K. Morality in groups: on the socialregulatory functions of right and wrong. Soc. Personal. Psychol. Compass 6, 878-889 (2012).

166. Boyer, P. \& Petersen, M. B. Folk-economic beliefs: an evolutionary cognitive model. Behav. Brain Sci. 41, 1-51 (2017).

167. Meegan, D. V. Zero-sum bias: perceived competition despite unlimited resources. Front. Psychol. 1, 191 (2010).

168. Folch, E., Hernandez, I., Barragan, M. \& Franco-Paredes, C. Infectious diseases, non-zero-sum thinking, and the developing world. Am. J. Med. Sci. 326, 66-72 (2003).

169. Goodwin, G. P. \& Landy, J. F. Valuing different human lives. J. Exp. Psychol. Gen. 143, 778-803 (2014).

170. Awad, E. et al. The Moral Machine experiment. Nature 563, 59-64 (2018).

171. Everett, J. A. C., Pizarro, D. A. \& Crockett, M. J. Inference of trustworthiness from intuitive moral judgments. J. Exp. Psychol. Gen. 145, 772-787 (2016).

172. Funk, C., Hefferon, M., Kennedy, B. \& Johnson, C. Trust and Mistrust in Americans' Views of Scientific Experts. Pew Research Center Science \& Society https://www.pewresearch.org/science/2019/08/02/trust-andmistrust-in-americans-views-of-scientific-experts/ (2019).

173. Ransohoff, K.J. Patients on the Trolley Track: The Moral Cognition of Medical Practitioners and Public Health Professionals. (Harvard Univ. Press, 2011).

174. Gino, F., Norton, M. I. \& Weber, R. A. Motivated Bayesians: feeling moral while acting egoistically. J. Econ. Perspect. 30, 189-212 (2016).

175. Garcia, T., Massoni, S. \& Villeval, M. C. Ambiguity and excuse-driven behavior in charitable giving. Eur. Econ. Rev. 124, 103412 (2020).

176. Kappes, A. et al. Uncertainty about the impact of social decisions increases prosocial behaviour. Nat. Hum. Behav. 2, 573-580 (2018).

177. Barclay, P. \& Willer, R. Partner choice creates competitive altruism in humans. Proc. Biol. Sci. 274, 749-753 (2007).

178. Milinski, M., Semmann, D. \& Krambeck, H.-J. Reputation helps solve the 'tragedy of the commons'. Nature 415, 424-426 (2002).

179. Cushman, F. \& Young, L. Patterns of moral judgment derive from nonmoral psychological representations. Cogn. Sci. 35, 1052-1075 (2011).

180. Ritov, I. \& Baron, J. Reluctance to vaccinate: omission bias and ambiguity. J. Behav. Decis. Making 3, 263-277 (1990).

181. Ritov, I. \& Baron, J. Status-quo and omission biases. J. Risk Uncertain. 5, 49-61 (1992).

182. Tetlock, P. E. \& Boettger, R. Accountability amplifies the status quo effect when change creates victims. J. Behav. Decis. Making 7, 1-23 (1994)

183. Nowak, M. A. Five rules for the evolution of cooperation. Science $\mathbf{3 1 4}$ 1560-1563 (2006).

184. Van Lange, P. A. M., Joireman, J. \& Milinski, M. Climate change: what psychology can offer in terms of insights and solutions. Curr. Dir. Psychol. Sci. 27, 269-274 (2018).

185. Milinski, M., Hilbe, C., Semmann, D., Sommerfeld, R. \& Marotzke, J. Humans choose representatives who enforce cooperation in social dilemmas through extortion. Nat. Commun. 7, 10915 (2016).

186. Reinders Folmer, C. P. et al. One for all: what representing a group may do to us. J. Exp. Soc. Psychol. 48, 1047-1056 (2012).

187. Yamagishi, T. The provision of a sanctioning system as a public good. J. Pers. Soc. Psychol. 51, 110-116 (1986).

188. Rand, D. G., Dreber, A., Ellingsen, T., Fudenberg, D. \& Nowak, M. A. Positive interactions promote public cooperation. Science 325, 1272-1275 (2009).

189. Dal Bó, E. \& Dal Bó, P. “Do the right thing:" the effects of moral suasion on cooperation. J. Public Econ. 117, 28-38 (2014).

190. Capraro, V., Jagfeld, G., Klein, R., Mul, M. \& de Pol, I. V. Increasing altruistic and cooperative behaviour with simple moral nudges. Sci. Rep. 9, 11880 (2019).

191. Fischbacher, U., Gächter, S. \& Fehr, E. Are people conditionally cooperative? evidence from a public goods experiment. Econ. Lett. 71 , 397-404 (2001).

192. Kraft-Todd, G., Yoeli, E., Bhanot, S. \& Rand, D. Promoting cooperation in the field. Curr. Opin. Behav. Sci. 3, 96-101 (2015).
193. Christensen, D., Dube, O., Haushofer, J., Siddiqi, B. \& Voors, M. Community-based crisis response: evidence from Sierra Leone's Ebola outbreak. Am. Econ. Rev. Pap. Proc. (in the press).

194. Tsai, L.L., Morse, B.S. \& Blair, R.A. Building credibility and cooperation in low-trust settings: persuasion and source accountability in Liberia during the 2014-2015 Ebola crisis. Comp. Polit. Stud. https://doi. org/10.1177/0010414019897698 (2020).

195. Blair, R. A., Morse, B. S. \& Tsai, L. L. Public health and public trust: survey evidence from the Ebola virus disease epidemic in Liberia. Soc. Sci. Med. 172, 89-97 (2017).

196. Morse, B., Grépin, K. A., Blair, R. A. \& Tsai, L. Patterns of demand for non-Ebola health services during and after the Ebola outbreak: panel survey evidence from Monrovia, Liberia. BMJ Glob. Health 1, e000007 (2016).

197. Vinck, P., Pham, P. N., Bindu, K. K., Bedford, J. \& Nilles, E. J. Institutional trust and misinformation in the response to the 2018-19 Ebola outbreak in North Kivu, DR Congo: a population-based survey. Lancet Infect. Dis. 19 529-536 (2019).

198. Alsan, M. \& Wanamaker, M. Tuskegee and the health of black men. Q. J. Econ. 133, 407-455 (2018).

199. Reicher, S., Haslam, S. A. \& Hopkins, N. Social identity and the dynamics of leadership: Leaders and followers as collaborative agents in the transformation of social reality. Leadersh. Q. 16, 547-568 (2005).

200. Haslam, S.A., Reicher, S.D. \& Platow, M.J. The New Psychology of Leadership: Identity, Influence, and Power. (Routledge, 2011).

201. Fransen, K. et al. Believing in "us": exploring leaders' capacity to enhance team confidence and performance by building a sense of shared social identity. J. Exp. Psychol. Appl. 21, 89-100 (2015).

202. Haslam, S. A. \& Reicher, S. Stressing the group: social identity and the unfolding dynamics of responses to stress. J. Appl. Psychol. 91, 1037-1052 (2006). Stressing the group.

203. Haslam, S. A. \& Platow, M. J. The link between leadership and followership: how affirming social identity translates vision into action. Pers. Soc. Psychol. Bull. 27, 1469-1479 (2001).

204. Hogg, M. A. A social identity theory of leadership. Pers. Soc. Psychol. Rev. 5, 184-200 (2001).

205. Nielsen, J.S. The Myth Of Leadership: Creating Leaderless Organizations. (Davies-Black Publishing, 2004).

206. Mooijman, M., van Dijk, W. W., van Dijk, E. \& Ellemers, N. On sanction-goal justifications: How and why deterrence justifications undermine rule compliance. J. Pers. Soc. Psychol. 112, 577-588 (2017).

207. Tyler, T.R. Why People Cooperate: The Role of Social Motivations. (Princeton Univ. Press, 2011).

208. Ellemers, N., Spears, R. \& Doosje, B. Self and social identity. Annu. Rev. Psychol. 53, 161-186 (2002).

209. Schnall, S., Roper, J. \& Fessler, D. M. T. Elevation leads to altruistic behavior. Psychol. Sci. 21, 315-320 (2010).

210. Schnall, S. \& Roper, J. Elevation puts moral values into action. Soc. Psychol. Personal. Sci. 3, 373-378 (2012).

211. Yang, X.-F., Pavarini, G., Schnall, S. \& Immordino-Yang, M. H. Looking up to virtue: averting gaze facilitates moral construals via posteromedial activations. Soc. Cogn. Affect. Neurosci. 13, 1131-1139 (2018).

212. de Zavala, A. G., Cichocka, A., Eidelson, R. \& Jayawickreme, N. Collective narcissism and its social consequences. J. Pers. Soc. Psychol. 97 1074-1096 (2009).

213. Cichocka, A. Understanding defensive and secure in-group positivity: the role of collective narcissism. Eur. Rev. Soc. Psychol. 27, 283-317 (2016).

214. Cichocka, A. \& Cislak, A. Nationalism as collective narcissism. Curr. Opin. Behav. Sci. 34, 69-74 (2020).

215. Cichocka, A., Marchlewska, M., Golec de Zavala, A. \& Olechowski, M. 'They will not control us': ingroup positivity and belief in intergroup conspiracies. Br. J. Psychol. 107, 556-576 (2016).

216. Baumeister, R. F. \& Leary, M. R. The need to belong: desire for interpersonal attachments as a fundamental human motivation. Psychol. Bull. 117, 497-529 (1995).

217. Jetten, J., Haslam, C., \& Haslam, S. A. (eds.) The Social Cure: Identity, Health and Well-being. (Psychology Press, 2012).

218. Jetten, J. et al. Advancing the social identity approach to health and well-being: progressing the social cure research agenda. Eur. J. Soc. Psychol. 47, 789-802 (2017).

219. Rimé, B. Emotion elicits the social sharing of emotion: theory and empirical review. Emot. Rev. 1, 60-85 (2009).

220. Williams, W. C., Morelli, S. A., Ong, D. C. \& Zaki, J. Interpersonal emotion regulation: Implications for affiliation, perceived support, relationships, and well-being. J. Pers. Soc. Psychol. 115, 224-254 (2018).

221. Haslam, C. et al. The New Psychology of Health: Unlocking the Social Cure. (Routledge, 2018).

222. Hawkley, L. C. \& Cacioppo, J. T. Loneliness matters: a theoretical and empirical review of consequences and mechanisms. Ann. Behav. Med. 40, 218-227 (2010). 
223. Luo, Y., Hawkley, L. C., Waite, L. J. \& Cacioppo, J. T. Loneliness, health, and mortality in old age: a national longitudinal study. Soc. Sci. Med. 74, 907-914 (2012).

224. Cacioppo, J.T. \& Patrick, W. Loneliness: Human Nature and the Need for Social Connection. (Norton, 2009).

225. Doré, B. P., Morris, R. R., Burr, D. A., Picard, R. W. \& Ochsner, K. N. Helping others regulate emotion predicts increased regulation of one's own emotions and decreased symptoms of depression. Pers. Soc. Psychol. Bull. 43, 729-739 (2017).

226. Helliwell, J. F. \& Huang, H. Comparing the happiness effects of real and on-line friends. PLoS One 8, e72754 (2013).

227. Verduyn, P. et al. Passive Facebook usage undermines affective well-being: experimental and longitudinal evidence. J. Exp. Psychol. Gen. 144, 480-488 (2015).

228. Schroeder, J., Kardas, M. \& Epley, N. The humanizing voice: speech reveals, and text conceals, a more thoughtful mind in the midst of disagreement. Psychol. Sci. 28, 1745-1762 (2017).

229. Waytz, A. \& Gray, K. Does online technology make us more or less sociable? a preliminary review and call for research. Perspect. Psychol. Sci. 13, 473-491 (2018).

230. Brooks, S. K. et al. The psychological impact of quarantine and how to reduce it: rapid review of the evidence. Lancet 395, 912-920 (2020).

231. Ellemers, N. \& Jetten, J. Pers. Soc. Psychol. Rev. 17, 3-21 (2013). The many ways to be marginal in a group.

232. Greenaway, K. H., Jetten, J., Ellemers, N. \& van Bunderen, L. The dark side of inclusion: undesired acceptance increases aggression. Group Process. Intergroup Relat. 18, 173-189 (2015).

233. Owen, L. Five ways the coronavirus is hitting women in Asia. BBC News https://www.bbc.com/news/world-asia-51705199 (2020).

234. Karney, B.R. Socioeconomic status and intimate relationships. Annu. Rev. Psychol. (in the press).

235. Karney, B.R. \& Neff, L.A. Couples and stress: how demands outside a relationship affect intimacy within the relationship. in The Oxford Handbook of Close Relationships (eds. Simpson, J. A. \& Campbell, L.) 664-684 (Oxford Univ.Press, 2013)

236. Cohan, C. L. \& Cole, S. W. Life course transitions and natural disaster: marriage, birth, and divorce following Hurricane Hugo. J. Fam. Psychol. 16, 14-25 (2002)

237. Finkel, E.J. The All-or-Nothing Marriage: How the Best Marriages Work. (Dutton, 2017).

238. Crum, A. J., Jamieson, J. P. \& Akinola, M. Optimizing stress: an integrated intervention for regulating stress responses. Emotion 20, 120-125 (2020).

239. Jamieson, J. P., Crum, A. J., Goyer, J. P., Marotta, M. E. \& Akinola, M. Optimizing stress responses with reappraisal and mindset interventions: an integrated model. Anxiety Stress Coping 31, 245-261 (2018).

240. Dienstbier, R. A. Arousal and physiological toughness: implications for mental and physical health. Psychol. Rev. 96, 84-100 (1989).

241. Epel, E. S., McEwen, B. S. \& Ickovics, J. R. Embodying psychological thriving: physical thriving in response to stress. J. Soc. Issues 54, 301-322 (1998).

242. Hazeldine, J., Arlt, W. \& Lord, J. M. Dehydroepiandrosterone as a regulator of immune cell function. J. Steroid Biochem. Mol. Biol. 120, 127-136 (2010).
243. Tedeschi, R. G. \& Calhoun, L. G. Posttraumatic growth: conceptual foundations and empirical evidence. Psychol. Inq. 15, 1-18 (2004).

244. Crum, A. J., Akinola, M., Martin, A. \& Fath, S. The role of stress mindset in shaping cognitive, emotional, and physiological responses to challenging and threatening stress. Anxiety Stress Coping 30, 379-395 (2017).

245. Crum, A. J., Salovey, P. \& Achor, S. Rethinking stress: the role of mindsets in determining the stress response. J. Pers. Soc. Psychol. 104, 716-733 (2013).

246. Soper, G. A. The lessons of the pandemic. Science 49, 501-506 (1919).

247. Byrne, S. \& Hart, P. S. The boomerang effect a synthesis of findings and a preliminary theoretical framework. Ann. Int. Commun. Assoc. 33 3-37 (2009).

248. Burgoon, M., Alvaro, E., Grandpre, J. \& Voulodakis, M. Revisiting the theory of psychological reactance: Communicating threats to attitudinal freedom. in The Persuasion Handbook: Developments in Theory and Practice (eds. Dillard, J. P. \& Pfau, M.) 213-232 (SAGE, 2002).

249. Garcia, D. \& Rimé, B. Collective emotions and social resilience in the digital traces after a terrorist attack. Psychol. Sci. 30, 617-628 (2019).

250. Brady, W. J., Crockett, M. \& Van Bavel, J. J. The MAD model of moral contagion: the role of motivation, attention and design in the spread of moralized content online. Persp. Psychol. Sci. (in the press).

251. Duncan, G. J., Brooks-Gunn, J. \& Klebanov, P. K. Economic deprivation and early childhood development. Child Dev. 65, 296-318 (1994).

252. Jin, R. L., Shah, C. P. \& Svoboda, T. J. The impact of unemployment on health: a review of the evidence. CMAJ 153, 529-540 (1995).

253. Rimal, R. N. \& Lapinski, M. K. Why health communication is important in public health. Bull. World Health Organ. 87, 247-247a (2009).

\section{Author contributions}

The corresponding authors (J.V.B and R.W.) came up with the idea for the paper, invited authors to collaborate, and wrote and edited the manuscript. All other contributing authors (K.B., P.S.B., V.C., A.C., M.C., M.J.C, A.J.C., K.M.D., J.N.D., J.D., O.D., N.E., E.J.F., J.H.F., M.G., S.H., S.A.H., J.J., S.K., D.M., K.E.N., D.J.P., G.P., E.P., R.E.P., D.G.R., S.D.R., S.S., A.S., L.J.S., S.S.S., C.R.S., N.T., J.A.T., S.V.L., P.A.M.V.L., K.A.W., M.J.A.W., J.Z. and S.R.Z.) wrote and edited the paper and are listed in alphabetical order. We thank J. Rothschild for his help in inserting citations and organizing the list of biographical references.

\section{Competing interests}

The authors declare no competing interests.

\section{Additional information}

Correspondence should be addressed to J.J.V.B. or R.W.

Reprints and permissions information is available at www.nature.com/reprints.

Publisher's note Springer Nature remains neutral with regard to jurisdictional claims in published maps and institutional affiliations.

Primary handling editor: Stavroula Kousta.

(c) Springer Nature Limited 2020 